\title{
Effect of Calcium Nitrate and Potassium Nitrate Priming on Seed Germination and Seedling Vigour of Papaya (Carica papaya L.)
}

\author{
Maneesha S.R. and Priya Devi S. \\ ICAR-Central Coastal Agricultural Research Institute, Ela, Goa - 403402 \\ Email: Maneesha.sr@icar.gov.in
}

\begin{abstract}
The effect of seed priming with calcium nitrate $\mathrm{Ca}\left(\mathrm{NO}_{3}\right)_{2}$ and potassium nitrate $\left(\mathrm{KNO}_{3}\right)$ on germination and seedling vigour were studied in papaya varieties. Open pollinated local (gauty) papaya seeds were soaked in $\mathrm{Ca}\left(\mathrm{NO}_{3}\right)_{2}$ and $\mathrm{KNO}_{3}$ solutions (10000 ppm, $15000 \mathrm{ppm}$ and $20000 \mathrm{ppm}$ ) up to 24 hours and germination percentage and seedling characteristics were recorded. The least number of days taken for seed germination (4.33 days), the highest germination percentage $(82.56 \%)$, the highest shoot length $(14.31 \mathrm{~cm})$ the highest fresh biomass $(1.36 \mathrm{~g})$ and dry biomass $(0.174 \mathrm{~g})$ were recorded in $10000 \mathrm{ppm} \mathrm{Ca}\left(\mathrm{NO}_{3}\right)_{2}$ treatment. Further, seeds of papaya varieties viz., Arka Surya, Arka Prabhat and Madhu bindhu were treated with 5000 ppm, $10000 \mathrm{ppm}$ and 15000 ppm $\mathrm{Ca}\left(\mathrm{NO}_{3}\right)_{2}$ and observed that Arka Prabhat seeds treated with $10000 \mathrm{ppm} \mathrm{Ca}\left(\mathrm{NO}_{3}\right)_{2}$ had taken the least number of days for germination (4.75 days) and also the highest shoot length $(25.2 \mathrm{~cm})$. The results of the experiment proved the significant effect of calcium ions over potassium ions on papaya seed germination and seedling vigour.
\end{abstract}

Keywords: Calcium nitrate, Papaya, Potassium nitrate, Seed germination and Seedling vigour.

\section{INTRODUCTION}

Papaya is one of the important tropical fruit crops cultivated in India. It is a highly nutritious with high amount of vitamin A $(258 \mu \mathrm{g})$, vitamin C $(60.90 \mathrm{mg})$ and folic acid $(37 \mu \mathrm{g})$. It also contain dietary fibers $(1.7 \mathrm{~g})$, calcium $(20 \mathrm{mg})$, iron $(0.25 \mathrm{mg})$, magnesium (21 mg), phosphorus (10 mg), potassium (182 mg), protein $(0.47 \mathrm{~g})$ and fat $(0.26 \mathrm{~g})$ (USDA, 2019). Papaya is mostly consumed as a fresh fruit and raw fruits are used as vegetable. Processed products like tutty fruity, jam and squash are prepared from papaya. Papain (vegetable pepsin) is a digestive enzyme extracted from mature unripe papaya, which is widely used in meat and leather industry as a tenderizing agent. The medicinal properties of papaya plant are also well exploited by pharmaceutical and cosmetic industries. Total area under papaya cultivation in India is 0.146 million hectare with a production of 6.096 million tonnes and productivity of 41.8 tonnes per hectare (Indiastat, 2019).

Commercially, papaya plant is propagated by seeds sown in protrays, poly bags or raised beds in nursery.
The seedlings are transplanted to the main field after 45 days maturity in the nursery. Earliness in seed germination and seedling growth at the nursery stage are the indicators of the vigour of the plant. Poor germination percentage, low seedling vigour and diseases like damping off and viral diseases are major problems faced by papaya growers in nursery stage. Stored papaya seeds germinate faster than the fresh seeds, but long storage period causes asynchronous and slow germination with low germination percentage (Andred et al., 2008). Seed germination is affected by internal factors like seed maturity, age of seeds, moisture condition of the seeds (Ellis et al., 1991), nutritional and health status of the mother plant and inhibitors present in the sarcotesta and seed coat (Reyes et al., 1980 and Chow and Lin, 1991). The external factors like storage conditions and duration of storage, $\mathrm{pH}$ and nutritional conditions of the growing media and biotic and abiotic stress factors also influence papaya seed germination. Heat shock induced stimulation of germination in pre-dried and reimbibed papaya seed were reported by Webster et al., (2016) They also reported the effect of 
exogenous application of gibberellic acid $\left(\mathrm{GA}_{3} \geq 250 \mu \mathrm{M}\right)$ to replace the heat shock stimulation. Seed treatments with chemicals or growth hormones are usually practiced in papaya for early and uniform seed germination and better seedling growth. Pre-sowing treatment of papaya seeds in 2.0$3.0 \mathrm{mM} \mathrm{GA}_{3}$ solution improves germination in papaya (Pandit et al., 2001). According to Marcos Filho (2015) osmopriming with chemical agents such as polyethylene glycol (PEG), calcium nitrate, and potassium nitrate activate germination of seeds by forming a water potential equilibrium between seeds and the solution by osmosis. External nitrogenous compounds can substitute costly plant growth substances, which are difficult to dissolve. Calcium nitrate and potassium nitrate are cheap and familiar chemicals with strong dissolving capacity. These cations can imbibe water fast and change the water potential of the seeds. Calcium nitrate pretreatment removed dormancy and enhanced germination in Brachiaria seeds (Silva et al., 2017). The priming of tomato seeds with $\mathrm{CaCl}_{2}$ and $\mathrm{KNO}_{3}$ solution was efficient to improve the seedling growth under salinity conditions (Ebrahimi et al., 2014). Batista et al. (2015) reported that the priming with $\mathrm{KNO}_{3}$ and $\mathrm{Ca}$ $\left(\mathrm{NO}_{3}\right)_{2}$ resulted in greater growth of pepper $(C$. frutescens) seedlings. The effectiveness of seed treatments varies with varieties in papaya (Rodriguez et al., 2019). Therefore, this experiment was constituted to study the effects of calcium and potassium ions on seed germination and seedling vigour of different papaya varieties.

\section{MATERIALS AND METHODS}

\section{Effect of $\mathrm{Ca}\left(\mathrm{NO}_{3}\right)_{2}$ and $\mathrm{KNO}_{3}$ on seed germination and plant biomass of local papaya var. Gauty}

In Goa and adjoining areas, an open pollinated tall papaya variety (Gauty) is commonly grown in the back yards. The tree will bear profusely with small round fruits with sweet yellow flesh. This local variety shows comparatively good field tolerance to Papaya Ring Spot Virus (PRSV) and other viral diseases. For this experiment, seeds were collected from the wellripened fruits and washed thoroughly in tap water to remove the sarcotesta (mucilaginous coat surrounding the seed). The seeds were shade dried and stored in butter paper covers under room temperature. The seeds were treated with three different concentrations
(10000 ppm, 15000 ppm and 20000 ppm) of Calcium Nitrate $\left(\mathrm{Ca}\left(\mathrm{NO}_{3}\right)_{2}\right)$ and Potassium Nitrate $(\mathrm{KNO})$. The treatment solutions were prepared on the same day of treatment application using distilled water. Fifty seeds were counted and soaked in the treatment solution for 24 hours. The next day the solutions were drained and the seeds were sown in the black polythene nursery bags $(20 \mathrm{~cm} \times 10 \mathrm{~cm})$ with drainage holes. The experimental design was completely randomized design with three replications.

Observations on days taken for germination, germination percentage, shoot length, root length, fresh weight of leaves, dry weight of leaves; leaf area, fresh biomass and dry biomass were recorded on 15 days after germination. Chlorophyll was extracted using $80 \%$ acetone and chlorophyll a, chlorophyll b, total chlorophyll and chlorophyll a/b ratio were estimated using spectrophotometer as per the method suggested by Arnon (1949). Specific leaf weight and specific leaf area were calculated by the standard formula given below.

Specific leaf Area (SLA) = Leaf area/ Leaf dry weight

Specific Leaf Weight $($ SLW $)=$ Leaf dry weight/ Leaf area

\section{Effect of $\mathrm{Ca}\left(\mathrm{NO}_{3}\right)_{2}$ on seed germination and seedling characteristics of important commercial varieties}

In this experiment, three varieties of papaya viz., Arka Surya, Arka Prabhat and Madhu bindu seeds were treated with three different concentrations of calcium nitrate (5000 ppm, $10000 \mathrm{ppm}$ and $15000 \mathrm{ppm})$. Experimental design was factorial completely randomized design (FCRD) with three replications. All other experimental procedures and observations were same as that of previous experiment. The data of both the experiments were analyzed in ANOVA at 0.05 probabilities using the statistical software WASP 2.0 of ICAR-CCARI, Goa.

\section{RESULTS AND DISCUSSION}

\section{Effect of $\mathrm{Ca}\left(\mathrm{NO}_{3}\right)_{2}$ and $\mathrm{KNO}_{3}$ on seed germination and plant biomass of local papaya var. Gauty}

The effect of $\mathrm{Ca}\left(\mathrm{NO}_{3}\right)_{2}$ and $\mathrm{KNO}_{3}$ at different levels (10000 ppm, $15000 \mathrm{ppm}$ and $20000 \mathrm{ppm}$ ) to the seeds 
of local (Gauty) papaya showed that, there is a significant influence of seed treatment on papaya seed germination. The least number of days taken for germination (4.33 days)) and the highest germination percentage $(82.56 \%)$, shoot length $(14.31 \mathrm{~cm})$, fresh biomass $(1.36 \mathrm{~g})$ and dry biomass $(0.174 \mathrm{~g})$ were recorded in $10000 \mathrm{ppm} \mathrm{Ca}\left(\mathrm{NO}_{3}\right)_{2}$ treatment. Number of leaves, fresh weight and dry weight of the leaves and leaf area showed non- significant difference between the treatments (Table 1). Effect of calcium ions on papaya seed germination was studied earlier by Bautista-Calles et al. (2008) and reported that, seeds treated for 4 days in $10^{\mathrm{m}} \mathrm{M}$ calcium chloride solution increased seed germination up to $262 \%$ and seedlings generated from treated seeds accumulated more biomass than the control seedlings. According to Salles et al. (2019), calcium nitrate enhanced the germination of eggplants in adverse environmental conditions.

Chlorophyll is the pigment molecule responsible for the light absorption and photosynthesis. The concentration of chlorophyll content in the leaves is an indication of the photosynthetic capacity and the productivity of the plant. Total chlorophyll content of the leaves, chlorophyll a, chlorophyll $\mathrm{b}$ and the chlorophyll $\mathrm{a} / \mathrm{b}$ ratio had no significant difference among the treatments (Fig. 1). Specific leaf area and specific leaf weight are parameters, which indirectly show the efficiency of photosynthesis. The partitioning of dry matter to leaf area is an important determinant of plant growth rate during early phases of development

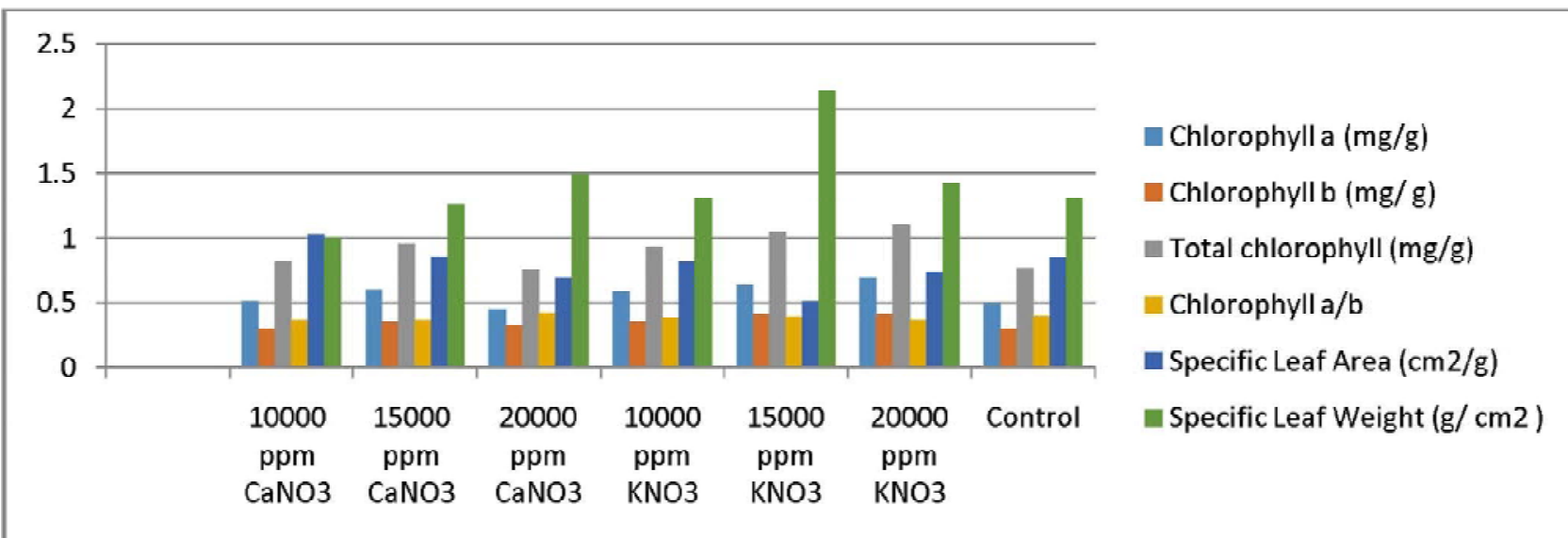

Fig. 1: Effect of calcium nitrate and potassium nitrate on physiological parameters of local (gauty) papaya variety

Table 1: Effect of calcium and potassium nitrate on germination and seedling vigour of local (gauty) papaya variety

\begin{tabular}{|c|c|c|c|c|c|c|c|c|c|}
\hline Treatments & $\begin{array}{l}\text { Days } \\
\text { taken for } \\
\text { germination }\end{array}$ & $\begin{array}{c}\text { Germi- } \\
\text { nation } \\
\%\end{array}$ & $\begin{array}{c}\text { Number } \\
\text { of } \\
\text { leaves }\end{array}$ & $\begin{array}{c}\text { Shoot } \\
\text { length } \\
(\mathrm{cm})\end{array}$ & $\begin{array}{c}\text { Fresh leaf } \\
\text { weight } \\
(\mathrm{mg})\end{array}$ & \begin{tabular}{|c|} 
Dry leaf \\
weight \\
(mg)
\end{tabular} & $\begin{array}{l}\text { Leaf } \\
\text { area } \\
\left(\mathrm{cm}^{2}\right)\end{array}$ & $\begin{array}{c}\text { Fresh } \\
\text { biomass } \\
\text { (g) }\end{array}$ & $\begin{array}{c}\text { Dry } \\
\text { biomass } \\
\text { (g) }\end{array}$ \\
\hline $\begin{array}{l}10000 \mathrm{ppm} \\
\mathrm{Ca}\left(\mathrm{NO}_{3}\right)_{2}\end{array}$ & $4.33^{\mathrm{a}}$ & $87.80^{\mathrm{a}}$ & 4.93 & $14.31^{\mathrm{a}}$ & 109.41 & 14.00 & 14.00 & $1.36^{\mathrm{a}}$ & $0.17^{\mathrm{a}}$ \\
\hline $\begin{array}{l}15000 \mathrm{pm} \\
\mathrm{Ca}\left(\mathrm{NO}_{3}\right)_{2}\end{array}$ & $6.00^{\mathrm{ab}}$ & $57.27^{\mathrm{ab}}$ & 4.92 & $11.67^{b}$ & 136.31 & 16.33 & 12.93 & $0.88^{\mathrm{b}}$ & $0.12^{b}$ \\
\hline $\begin{array}{l}20000 \mathrm{ppm} \\
\mathrm{Ca}\left(\mathrm{NO}_{3}\right)_{2}\end{array}$ & $7.00^{\mathrm{abc}}$ & $66.03^{b}$ & 3.87 & $12.11^{\mathrm{abc}}$ & 89.10 & 14.66 & 10.31 & $0.77^{\mathrm{bc}}$ & $0.09^{c}$ \\
\hline 10000 ppm $\mathrm{KNO}_{3}$ & $8.00^{\mathrm{bc}}$ & $43.59^{b}$ & 4.33 & $10.92^{\mathrm{abc}}$ & 98.33 & 14.67 & 11.25 & $0.67^{\mathrm{c}}$ & $0.05^{\mathrm{c}}$ \\
\hline 15000 ppm $\mathrm{KNO}_{3}$ & $7.67^{\mathrm{c}}$ & $48.72^{\mathrm{b}}$ & 4.23 & $9.31^{\mathrm{bc}}$ & 90.00 & 19.67 & 10.54 & $0.53^{b}$ & $0.09^{c}$ \\
\hline $20000 \mathrm{ppm} \mathrm{KNO}_{3}$ & $7.33^{d}$ & $48.72^{b}$ & 4.22 & $13.26^{\mathrm{ab}}$ & 101.83 & 17.00 & 12.27 & $1.01^{\mathrm{c}}$ & $0.12^{\mathrm{b}}$ \\
\hline Control & $8.33^{\mathrm{e}}$ & $43.59^{b}$ & 4.13 & $10.42^{\mathrm{bc}}$ & 90.46 & 13.33 & 10.42 & $0.42^{\mathrm{c}}$ & $0.04^{\mathrm{c}}$ \\
\hline $\mathrm{CD}(0.05)$ & 0.76 & 27.42 & NS & 3.08 & NS & NS & NS & 0.41 & 0.05 \\
\hline
\end{tabular}


(Potter and Jones, 1977; Nelson, 1988).Specific leaf weight (leaf weight/leaf area) has been positively correlated with photosynthesis per unit of leaf area for genotypes of many species (Nelson, 1988). However, in this experiment, the results showed that, the seed treatments have no significant role in the photosynthetic efficiency of the plants.

Effect of $\mathrm{Ca}\left(\mathrm{NO}_{3}\right)_{2}$ on seed germination and seedling characteristics of important commercial varieties

Three varieties of papaya (Arka Surya, Arka Prabhat and Madhu bindhu) were treated with $\mathrm{CaNO}_{3}$ at different levels (5000 ppm, $10000 \mathrm{ppm}$ and 15000 ppm) along with control. Among the three varieties, Arka Prabhat treated with 10000 ppm $\mathrm{Ca}\left(\mathrm{NO}_{3}\right)_{2}$ recorded the lowest number of days taken for germination (4.75 days) and the highest shoot length $(25.2 \mathrm{~cm})$. Fresh weight of the leaves, dry weight of the leaves, leaf area and specific leaf weight were also estimated (Table 2). The experiment proved the significant effect of calcium ions in the papaya seed germination at low concentration.

The interaction effect of the three varieties with the three different concentration of calcium nitrate treatment showed that, Arka Prabhat treated with $5000 \mathrm{ppm}$ and $10000 \mathrm{ppm}$ calcium Nitrate had taken the least number of days for germination. The highest germination percentage was recorded in Arka Prabhat treated with $5000 \mathrm{ppm}$ calcium nitrate (87.85\%). Shoot length, fresh weight of the leaves, dry weight of the leaves, leaf area and specific leaf weight was

Table 2: Effect of $\mathrm{Ca}\left(\mathrm{NO}_{3}\right)_{2}$ on seed germination and seedling vigour of papaya varieties

\begin{tabular}{|c|c|c|c|c|c|c|c|c|}
\hline Treatments & $\begin{array}{l}\text { Days taken } \\
\text { for } \\
\text { germination }\end{array}$ & $\begin{array}{c}\text { Germi- } \\
\text { nation } \\
\%\end{array}$ & $\begin{array}{c}\text { Number } \\
\text { of } \\
\text { leaves }\end{array}$ & $\begin{array}{c}\text { Shoot } \\
\text { length } \\
(\mathrm{cm})\end{array}$ & $\begin{array}{c}\text { Fresh } \\
\text { biomass } \\
\text { (g) }\end{array}$ & $\begin{array}{c}\text { Dry } \\
\text { biomass } \\
\text { (g) }\end{array}$ & $\begin{array}{l}\text { Leaf } \\
\text { area } \\
\left(\mathbf{m m}^{2}\right)\end{array}$ & $\begin{array}{c}\text { Specific } \\
\text { leaf area } \\
\left(\mathrm{mm}^{2} / \mathrm{g}\right)\end{array}$ \\
\hline V1 (Arka Surya) & 5.50 & 70.40 & 6.50 & 20.49 & 0.37 & 0.18 & 3388.13 & 1949.16 \\
\hline V2 (Arka Prabhat) & 4.75 & 70.40 & 5.90 & 20.95 & 0.51 & 0.30 & 4682.75 & 1668.22 \\
\hline V3(Madhu bindhu) & 6.50 & 78.99 & 6.25 & 18.63 & 0.47 & 0.26 & 3936.00 & 1504.51 \\
\hline $\mathrm{CD}(0.05)$ & 0.62 & 12.40 & 0.82 & 2.77 & 0.10 & 0.04 & 902.20 & 421.61 \\
\hline $\mathrm{C} 1\left(5000 \mathrm{ppm} \mathrm{Ca}\left(\mathrm{NO}_{3}\right)_{2}\right)$ & 5.33 & 85.77 & 6.67 & 21.75 & 0.44 & 0.24 & 4188.50 & 1933.09 \\
\hline $\mathrm{C} 2\left(10000 \mathrm{ppm} \mathrm{Ca}\left(\mathrm{NO}_{3}\right)_{2}\right)$ & 5.50 & 72.92 & 6.33 & 22.37 & 0.42 & 0.22 & 3871.33 & 1783.47 \\
\hline $\mathrm{C} 3\left(20000 \mathrm{ppm} \mathrm{Ca}\left(\mathrm{NO}_{3}\right)_{2}\right)$ & 5.50 & 71.88 & 6.33 & 21.12 & 0.53 & 0.26 & 4415.50 & 1718.51 \\
\hline $\mathrm{C} 4($ Control) & 6.00 & 62.50 & 5.50 & 14.85 & 0.42 & 0.27 & 3533.83 & 1394.12 \\
\hline $\mathrm{CD}(0.05)$ & 0.72 & 14.31 & 0.95 & 3.20 & 0.12 & 0.05 & 1041.77 & 486.84 \\
\hline $\mathrm{V} 1 \mathrm{Cl}$ & 4.50 & 84.73 & 7.00 & 20.90 & 0.30 & 0.12 & 3110.00 & 2574.64 \\
\hline $\mathrm{V} 1 \mathrm{C} 2$ & 5.50 & 68.75 & 6.00 & 20.95 & 0.43 & 0.21 & 4159.00 & 2031.32 \\
\hline $\mathrm{V} 1 \mathrm{C} 3$ & 6.00 & 65.63 & 6.50 & 24.20 & 0.48 & 0.23 & 4042.00 & 1756.80 \\
\hline V1C4 & 6.00 & 62.50 & 6.50 & 15.90 & 0.27 & 0.15 & 2241.50 & 1433.90 \\
\hline $\mathrm{V} 2 \mathrm{C} 1$ & 5.00 & 87.85 & 6.50 & 24.95 & 0.50 & 0.29 & 5760.50 & 1981.77 \\
\hline $\mathrm{V} 2 \mathrm{C} 2$ & 4.50 & 65.63 & 6.00 & 25.20 & 0.43 & 0.21 & 4140.00 & 1960.28 \\
\hline $\mathrm{V} 2 \mathrm{C} 3$ & 4.50 & 65.63 & 6.00 & 20.45 & 0.63 & 0.30 & 4892.00 & 1738.45 \\
\hline $\mathrm{V} 2 \mathrm{C} 4$ & 5.00 & 62.50 & 5.00 & 13.20 & 0.48 & 0.40 & 3938.50 & 992.36 \\
\hline $\mathrm{V} 3 \mathrm{Cl}$ & 6.50 & 84.73 & 6.50 & 19.40 & 0.51 & 0.30 & 3695.00 & 1242.87 \\
\hline $\mathrm{V} 3 \mathrm{C} 2$ & 6.50 & 84.38 & 7.00 & 20.95 & 0.40 & 0.25 & 3315.00 & 1358.81 \\
\hline $\mathrm{V} 3 \mathrm{C} 3$ & 6.00 & 84.38 & 6.50 & 18.70 & 0.49 & 0.25 & 4312.50 & 1660.28 \\
\hline V3C4 & 7.00 & 62.50 & 5.00 & 15.45 & 0.49 & 0.25 & 4421.50 & 1756.09 \\
\hline $\mathrm{CD}(0.05)$ & 1.24 & 24.79 & 1.64 & 5.539 & 0.21 & 0.09 & 1804.39 & 843.22 \\
\hline
\end{tabular}


higher in Arka Prabhat variety treated with 10000 ppm calcium nitrate. Gouveia et al. (2017) reported that the priming of corn seeds with calcium nitrate and phenylalanine promoted greater germination rate of low vigour seeds. The priming of cucumber seeds with potassium nitrate showed little effect in improving the germination and growth rate of seedlings under salt stress conditions (Oliveira and Steiner, 2017). Reis et al. (2012) also reported that $\mathrm{KNO}_{3}$ priming resulted in higher germination rate and lower mean germination time in eggplant cv. Embu. From the results, it is very clear that the seed priming with calcium nitrate at low concentration can hasten and improve the germination of papaya, but there is no significant effect in the further growth.

\section{REFERENCES}

Andrade, M., J. Ayala, I. Alia, H. Rodríguez, C. Acosta and V. López. 2008. Effect of germination promoters and substrates in the development of papaya seedlings. Revista de la Facultad de Agronomía-LUZ. 25:617635.

Batista, T. B., F. F. S. Binotti, E.D. Cardoso, E.M. Bardiviesso and E. Costa. 2015. Physiological aspects and quality of pepper seedlings in response to the vigor and conditioning of seeds. Bragantia, 74(4): 367-373. https://doi.org/10.1590/16784499.0133 .

Bautista-calles,F., Guillermo carrillo-castañed, Angel villegas-monter. 2008. Recuperation of the high germinability condition of papaya seed through priming technology and bioregulators. Agrociencia. 42(7):817-826.

Chow, Y.J. and C.H. Lin.1991. p-Hydroxy benzoic acid as the major phenolic germination inhibitor of papaya seed. Seed Science and Technology. 19:167-174.

Ebrahimi, R., Ahmadizadeh, M., and Rahbarian, P. (2014). Enhancing stand establishment o f tomato cultivars under salt stress condition. Journal Horticulture, Biology and Environ-ment, 5(1): 19-42. https://doi.org/ 10.1007/s13580-014-0032-7.

Ellis, R.H., T.D. Hong and E. H. Roberts. 1991. Effect of storage temperature and moisture on the germination of papaya seeds. Seed Science Research.1:69-72.

Gouveia, G. C. C., Binotti, F. F. S., and Costa, E. (2017). Priming effect on the physiological potential of maize seeds under abiotic stress. Pesquisa Agropecuária Tropical, 47(3),328-335.https://doi.org/10.1590/1983$40632016 v 4746560$.

https://www.indiastat.com/agriculture/2/ fruitsandnuts/17426/papaya/17444/stats.aspx. retrieved on 15.10.2019.

Marcos Filho, J. 2015. Fisiologia de sementes de plantas cultivadas. Londrina: ABRATES. (p. 659).

Nelson, C.J., 1988. Genetic association between photosynthetic characteristics and yield: Review of the evidence. Plant Physiol. Biochem., 26: 543-554.

Pandit, V. K., N. Shantha and J.P. Sinha. 2001.Improving papaya (Carica papaya) seed germination and seedling growth by presowing treatments. Indian Journal of Agricultural Sciences 71 (11): 704-706.

Potter, J.R. and Jones, J.W., 1977. Leaf area partitioning as an important factor in growth. Plant Physiol., 59: 10-14.

Reyes, M.N., A. Perez and J. Cuevas.1980. Detecting endogenous growth regulators on the sarcotesta, endosperm and embryo by paper chromatography on fresh and old seeds of two papaya varieties. Journal of Agriculture-University of Puerto Rico. 64:164-172.

Rodriguez,S., I. Vargas, A. Hijuelo, F. Loumeto, J. J. Silva, J. Perez, Q. Arias, Y. Fonseca, Y. Gomez, M. Baldoquin and D. Oliva.2019.Analysis of the effect of 
scarification process on papaya (Carica papaya Lin.) Seeds Germination DOI: http://dx.doi.org/10.5772/intechopen. 88012

Salles, J.S., A. H. F. de Lima, F. F. da S. Binotti, E. Costa, E. D. C. Binotti, J. S. Salles, G. H. da C. Vieira1 and Andreia F. G. O. de Souza. 2019.Calcium nitrate priming increases the germination rate of eggplant seeds. Journal of Agricultural Science. 11(5): 181-186.

Silva, A.G., Paula, R. C. M., Binotti, F. F. S. and E. Costa. 2017. Comportamento germinativo de sementes de eucalipto em duas temperaturas com o uso de sais inorgânicos. Enciclopédia Biosfera,14(25): 358-364. https://doi.org/ 10.18677/EnciBio_2017A33.

USDA-National Nutrient Database for Standard Reference Release. 2016. Retrieved on 05.11.2019.

Webster, R.E., W.M. Waterworth, W. Stuppy, C.E. West, R. Ennos, C.M. Bray and H.W. Pritchard. 2016.Biomechanical, biochemical, and morphological mechanisms of heat shock-mediated germination in Carica papaya seed. J Exp. Bot.67 (22) : 63736384.

(Received on 25.9.2019, Revised on 2.12.2019 and accepted on 6.12.2019) 